\begin{tabular}{|c|c|c|}
\hline & International Journal of Current Research in & \\
\hline & Biosciences and Plant Biology & $\frac{1}{2}+0$ \\
\hline PUBL & $\begin{array}{c}\text { ISSN: 2349-8080 (Online) • Volume } 3 \bullet \text { Number } 4 \\
\text { Journal homepage: www.ijcrbp.com }\end{array}$ & \\
\hline
\end{tabular}

\title{
Comparative Bioefficacy of Fungicides and Trichoderma spp. against Pestalotiopsis theae, Causing Grey Blight in Tea (Camellia sp.): An In Vitro Study
}

\author{
Kishor Chand Kumhar*, Azariah Babu, Mitali Bordoloi, Priyanka Benarjee and \\ Hirakjyoti Rajbongshi
}

Tea Research Association, North Bengal Regional Research \& Development Centre, Nagrakata, Jalpaiguri - 735 225, West Bengal, India

*Corresponding author.

\begin{abstract}
A bstract
The grey blight, caused by Pestalotiopsis theae is a serious problem in almost all tea growing regions of India. A large number of tea cultivars were found to be susceptible to this disease. Evaluation of four selected fungicides (carbendazim 12\% a.i + mancozeb $63 \%$ a.i., hexaconazole $5 \mathrm{EC}$, copper oxychloride $50 \mathrm{WP}$ and copper hydroxide $77 \mathrm{WP}$ ) have been found effective in suppressing the pathogen to the considerable degree under in vitro conditions. Results indicated that, maximum control (70.8\%) was achieved in the case of combi fungicidal formulation (carbendazim $12 \%$ a. i. + mancozeb $63 \%$ a. i.) followed by hexaconazole $5 \mathrm{EC}$ and copper hydroxide $77 \mathrm{WP}$ and copper oxychloride $50 \mathrm{WP}$, respectively. Effort has been made to evaluate the effectiveness of the indigenous Trichoderma viride (KBN-24) and T. asperellum (KBN-29) in inhibiting the mycelial growth of $P$. theae in dual culture method and the results indicated significant inhibition of the pathogen. Results on the compatibility study indicated that the tested fungicides adversely affected the growth of $T$. viride to varying degree. The maximum inhibition (79.0\%) was noted in case of combi fungicide formulation followed by copper oxychloride $(75.8 \%)$ and hexaconazole $(70.4 \%)$. Thus the results of this current investigation highlighted the fact that the local Trichoderma isolates were found effective in controlling the targeted phytopathogen. However, use of such fungicides soon after the application of Trichoderma formulation, should be discouraged to have a better control of the disease.
\end{abstract}

\section{Article Info}

Accepted: 10 March 2016

Available Online: 06 April 2016

Ke ywords

Fungicide compatibility

Pathogenicity

Pestalotiopsis theae

Tea plant

Trichoderma asperellum

Trichoderma viride

\section{Introduction}

The grey blight disease of tea (Camellia sp.) caused by Pestalotiopsis theae (Ascomycota, Amphisphaeriaceae), is one of the limiting factors which affect the quality and quantity of tea. It is capable of infecting several plants of economic importance including guava, mango etc. Its infection is manifested by the development various kinds of symptoms (Hopkins and McQuilken, 2000; Keith et al., 2006; Pirone, 1978; Kwee and Chong, 1990;
Xu et al., 1999; Tagne and Mathur, 2001; Sousa et al., 2004; Espinoza et al., 2008). In general, it infects the maintenance leaves of tea which ensures the nourishment to the young shoots and tender foliage that ultimately results in huge crop loss (Joshi et al. 2009, Horikawa 1986). Being a week pathogen (Madar et al., 1991) it invades the tea leaves through stomata, lenticels, hydathodes and also through the mechanical wounds (Agrios, 2005). The genus Pestalotiopsis is anamorphic and does not possess sexual morphogenesis (Armstrong- 
Cho and Banniza, 2006; Wulandari et al., 2009). Its sexual state or teleomorph have been identified as Pestalosphaeria and Neobroomella (Barr, 1975; Kirk et al., 2008). The mode of infection has reported to be either by means of asexual conidia or fragmented spores (Espinoza et al., 2008). These conidia could survive during harsh weather conditions and may cause primary infection during favorable weather conditions. The plants subjected to abiotic stress are more susceptible to infection of this pathogen (Elliott et al., 2004; McQuilken and Hopkins, 2004; Keith et al., 2006). The source of the primary infection emanate from wild plantations (Keith et al., 2006), flowers (Pandey, 1990), crop debris, soil, contaminated nursery tools (McQuilken and Hopkins, 2004), splashed water droplets (Hopkins and McQuilken, 1997; Elliott et al., 2004) and also air borne spores (Xu et al., 1999).

For the successful control of this pathogen, different chemical fungicides have been used since last several years, but their frequent applications had invited numerous associated problems including the residues in made tea which is a burning issue. To minimize such problems, integrated disease management approach is most acceptable one, which is considered as the need of the hour that has gained wide popularity nationally as well as internationally, in different cropping systems. Biological control agents (BCAs) particularly
Trichoderma spp. could be an important component of such integration. This antagonistic genus has proven efficient in controlling a wide range of phytopathogens (Dominguesa et al., 2000) of different crops through different modes of action (Elad et al., 1982; Papavizas, 1985; Taylor, 1986; Ridout et al., 1988) in eco-friendly manner. Our present study has highlighted the disease incidence, pathogenicity of Pestalotiopsis theae. under lab as well as field conditions, bio-efficacy of different chemical fungicides and the indigenous isolates of Trichoderma spp. apart from the compatibility of fungicides with antagonist.

\section{Materials and methods}

\section{Disease survey in tea plantation}

To determine the frequency of grey blight disease occurrence, a total of ten tea gardens of Dooars region in West Bengal, India, were randomly selected and surveyed during active season (April to October, 2015). In each garden, from the selected fields, samples of maintenance foliage were randomly drawn and assessed for the presence of the disease. Similarly, at our experimental plot, sampling was done from thirty five different tea cultivars. The samples showing the presence of disease symptoms (Fig.1A and 1B) were categorized and considered as susceptible / disease prone cultivar in this survey.
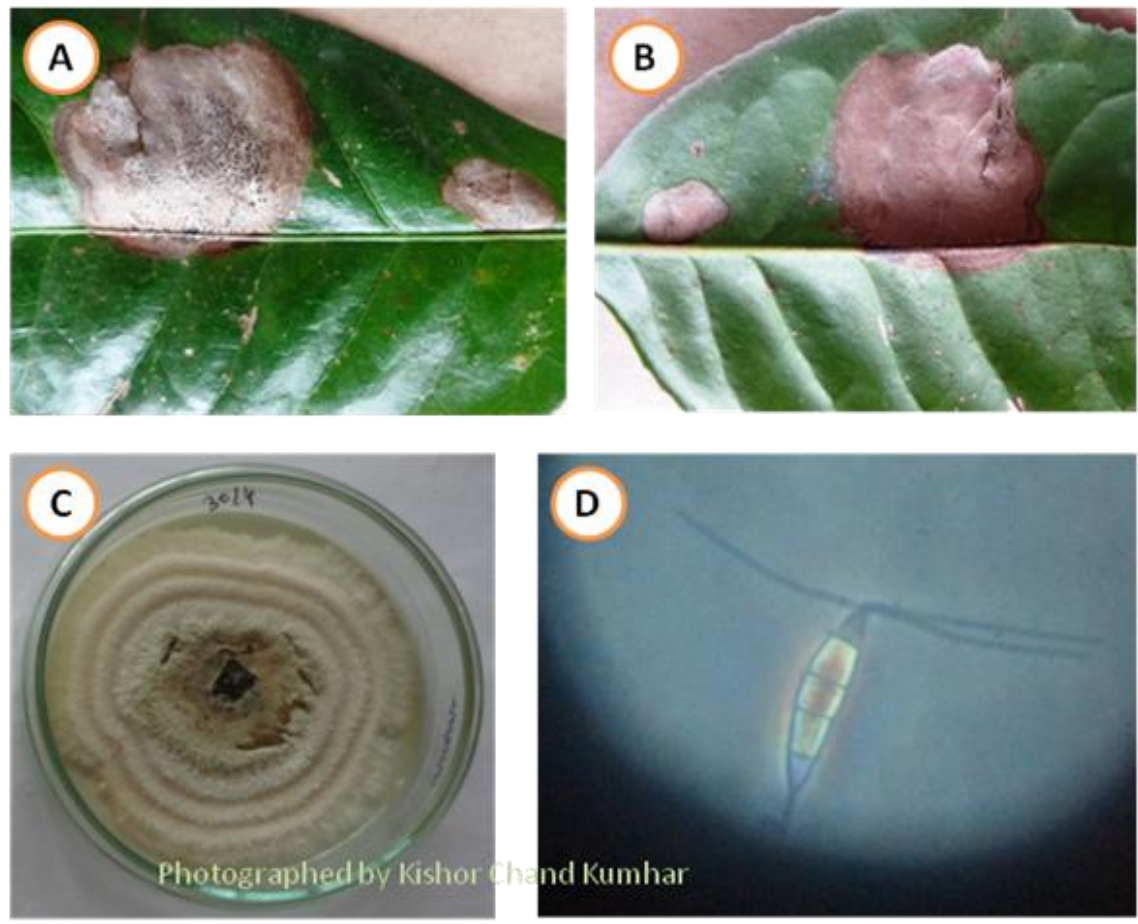

Fig. 1: Grey blight symptom on infected tea leaf (A: adaxial leaf surface; B: abaxial leaf surface) and isolated pathogen (C: mycelial colony; D: conidia of $P$. theae). 


\section{Isolation and determination of pathogenicity of pathogen}

The isolation of the pathogen was done by adopting the technique of Vidhya Pallavi et al. (2012) with minor modifications. The in vitro and in vivo pathogenicity of pathogen was carried out by employing pin pricking method (Mondal et al., 2015) followed by inoculation. For this purpose, the conidial suspension was prepared from actively growing culture of $P$. theae. Twenty milliliter of distilled sterilized water was added to plate $(90 \mathrm{~mm}$ diameter) and fungal biomass (conidia and mycelia) was harvested. This suspension was further diluted serially to get optimum conidial strength of $2 \times 10^{6} \mathrm{cfu} / \mathrm{ml}$, and finally the leaves were inoculated with the fungus. Development of symptom was recorded up to one week for the confirmation of its virulence. The establishment of host - pathogen interaction was confirmed by visualizing the slide of infected leaf through compound microscope (Olympus - BX51) at 40X magnification.

\section{In vitro bio-efficacy fungicides against pathogen}

The bio-efficacy of a few fungicides against grey blight pathogen was carried out by poisoned food technique (Nene and Thapliyal, 1993) using potato dextrose agar medium (Hi-Media). Required quantities of fungicides were added in to medium and then it was poured in to plates (90 $\mathrm{mm}$ dia). After solidification, 5 $\mathrm{mm}$ diameter discs of pathogen's mycelia were inoculated in the centre of plates followed by incubation at $25 \pm 2^{\circ} \mathrm{C}$ for two weeks. Each treatment was replicated five times. Growth inhibition was worked out by following formula:

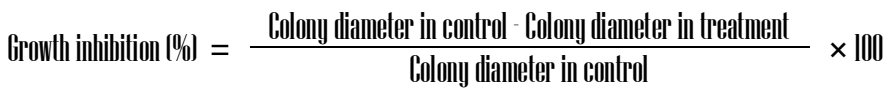

\section{In vitro bio-efficacy of Trichoderma spp.}

To assess the bio-efficacy of Trichoderma spp., dual culture technique (Stack et al., 1986) was employed. Five millimeter discs of both fungi (Trichoderma spp. and $P$. theae) were incubated at equidistance in the centre of the plates followed by incubation at $25 \pm 2^{\circ} \mathrm{C}$ for one week. Each treatment was replicated five times. Pathogen's mycelial growth was measured after one week. Mycelial colony diameter was measured and growth inhibition was worked out using the above mentioned formula.

\section{Fungicide compatibility with Trichoderma sp.}

The recommended dose of each fungicide was evaluated by adopting poisoned food technique of Nene and Thapliyal (1993). Accordingly, required quantity of each fungicide was measured and admixed thoroughly in to hundred $\mathrm{mL}$ PDA medium before pouring it in to the plates ( $90 \mathrm{~mm}$ diameter). After solidification, $5 \mathrm{~mm}$ diameter mycelial discs of $T$. viride were inoculated in the centre of plates followed by incubation at $25 \pm 2^{\circ} \mathrm{C}$. Each treatment was replicated five times. The colony diameter was measured followed by calculation of per cent growth inhibition using formula described earlier.

\section{Statistical analysis}

To compare critical difference, all experimental data were analyzed statistically through online package 'OPSTAT' of Chaudhary Charan Singh Haryana Agricultural University, Hisar, Haryana, India.

\section{Results and discussion}

\section{Disease survey in tea plantation}

Our study indicated that grey blight disease was ubiquitously prevalent in almost all surveyed tea garden of different locations. Similarly, at the experimental plot, sampling done from thirty five different tea cultivars (Table 1) showed the wide occurrence of grey blight pathogen irrespective of tea cultivar. Earlier researchers noted that certain tea cultivars such as Teen Ali-17/1/54 and TV-23 were highly susceptible, however cultivar CP-1 and TV-26 were less susceptible to grey blight pathogen (Chakraborty et al., 1995), which supported our findings. The disease susceptibility or tolerance of plant is governed by quantity of many anti-oxidative enzymes i.e. glutathione reductase (GR), superoxide dismutase (SOD), catalase (CAT), ascorbate peroxidase (APO), peroxidase (POD) and polyphenol oxidase (PPO), which was found higher concentration in susceptible cultivars as reported by Palanisamy and Mandal (2014).

\section{Isolation of pathogen and determination of its pathogenicity}

The isolated pathogen, based cultural characteristics and conidial morphology, was identified as $P$. theae. The microscopic observations confirmed that its conidia were 5 celled. The conidial upper and lower cells were hyaline, however, rest median three cells were dark 
colored. Its conidia possessed 2-3 setullae at the apex and one pedicel at the bottom as clear from Figs. 1C and 1D.

The 'pin pricking method' under lab conditions resulted in the successful establishment of the infection of this pathogen, which was manifested in the development of necrotized area in the form of 'leaf spot'. The clear cut disease symptoms became evident only after $72 \mathrm{hrs}$ of inoculation, which has undergone complete development within 7 days (Fig. 2A).

However, under field conditions, the leaf necrosis appeared after 72-96 hours around the inoculation site (Fig. 2B) and the prominent symptoms were visible only after 8-10 days of inoculation (Fig. 2C). Microscopic visualization of adjoining infected area of leaves revealed that, there was positive host-pathogen interaction. Hence pathogen could successfully establish itself in to leaf tissues and efficiently produced conidia therein (Fig. 2 D). The re-isolation of pathogen from necrotized tissue justified the Koch's postulates positive.

A few isolates of Pestalotiopsis spp. isolated from different tea growing areas of southern India which exhibited diversity in morphological characteristics including size and color of conidia as well as virulence have been reported (Joshi et al., 2009). Similarly a survey in mango orchards has been undertaken and isolation of this pathogen was carried out (Okigbo and Osuinde, 2003).

Table 1. Survey of grey blight disease of tea during 2015.

\begin{tabular}{llll}
\hline Selected tea garden & Total sample surveyed & Sample infected & Disease occurrence \\
\hline Garden 1 & 5 & 5 & + \\
Garden 2 & 5 & 5 & + \\
Garden 3 & 5 & 5 & + \\
Garden 4 & 5 & 5 & + \\
Garden 5 & 5 & 5 & + \\
Garden 6 & 5 & 5 & + \\
Garden 7 & 5 & 5 & + \\
Garden 8 & 5 & 5 & + \\
Garden 9 & 5 & 5 & + \\
Garden 10 & 5 & 5 & + \\
TRA Experimental plot & 35 & 35 & \\
\hline
\end{tabular}

+ indicated disease
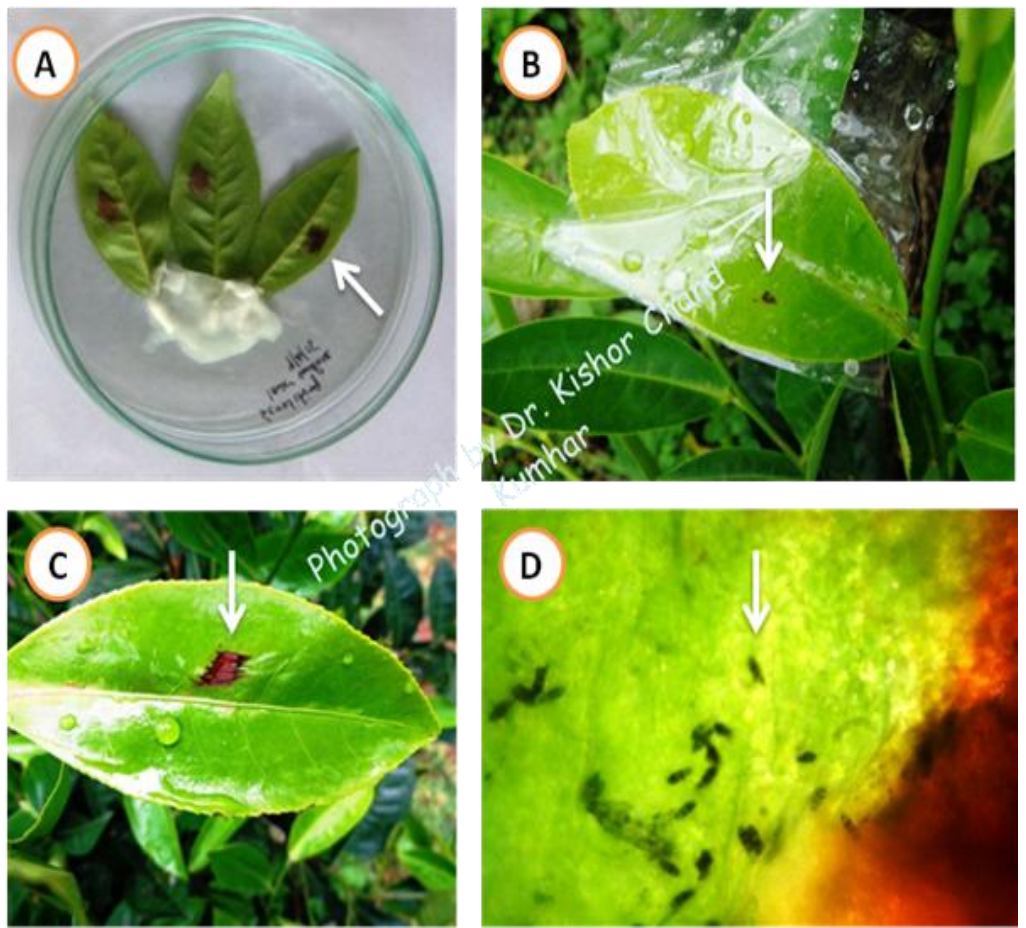

Fig. 2: Pathogenecity of $P$. theae (A: In vitro; B-D: In vivo). 


\section{In vitro bio-efficacy fungicides against pathogen}

The results of the in vitro bio-efficacy of fungicides against pathogen indicated that all the four tested fungicides affected the growth of $P$. theae to a variable degree. The combi fungicidal formulation (carbendazim @ 12\% a. i.plus mancozeb @ 63\% a. i.) was found to be the most effective one in controlling the pathogen (76.4\%) followed by hexaconazole copper hydroxide and copper oxychloride (Table 2), at their respective recommended doses. Ponmurugan et al. (2006) reported carbendazim as the most effective in controlling $P$. theae followed by dithane M-45. Several systemic as well as contact fungicides viz., tebuconazole, tridemorph, azoxystrobin, hexaconazole, triflumizole, bitertanol, copper oxychloride and copper hydroxide were tested against $P$. theae by Sarkar et al. (2009) and they found that bitertanol and hexaconazole were highly toxic to this pathogen when compared with copper fungicides.

\section{In vitro bio-efficacy of Trichoderma spp.}

The indigenous Trichoderma isolates inhibited the growth of $P$. theae to the tune of 53.8 to $62.5 \%$ after 7 days indicating the bio-efficacy of the tested isolates against the pathogen, $P$. theae. However, among the two isolates of Trichoderma, the maximum growth inhibition was noted in case of $T$. asperellum (KBN29) followed by $T$. viride (KBN 24). However, both species were found statistically at par (Table 3). Vidhya Pallavi et al. (2010) noted that under lab conditions, Trichoderma spp. exhibited a very good antagonistic potentiality against the grey blight (Pestalotiopsis sp.) and wood rot (Hypoxylon sp.) pathogens of tea. Similarly, Naglot et al. (2015) tested several isolates of Trichoderma spp. and reported their antagonistic potency for the control of this pathogen and these findings are in agreement with our results.

Table 2: Growth inhibitory effect of fungicides on $P$. theae.

\begin{tabular}{llll}
\hline Fungicide & $\begin{array}{l}\text { Fungicide } \\
\text { conc. }(\mathbf{p p m})\end{array}$ & $\begin{array}{l}\text { Fungicide quantity }(\mathbf{g} / \mathbf{m L}) \\
\text { per 100 } \mathbf{~ m L ~ P D A}\end{array}$ & $\begin{array}{l}\text { Per cent growth inhibition } \\
\text { over control* }^{*}\end{array}$ \\
\hline Copper oxychloride 50 WP & 2500 & 0.25 & $69.4(56.5 \pm 1.3)$ \\
Carbendazim 12\% a.i + mancozeb 63\% a.i. & 2500 & 0.25 & $76.4(61.0 \pm 1.1)$ \\
Hexaconazole 25 EC & 1000 & 0.1 & $75.9(60.6 \pm 1.0)$ \\
Copper hydroxide 77 WP & 2500 & 0.25 & $71.6(57.8 \pm 1.3)$ \\
C.D. & & & 3.6 \\
SE(m) & & & 1.2 \\
SE(d) & & 1.7 \\
C.V. & & 4.5 \\
\hline
\end{tabular}

*Values represent mean of 5 replications, figures in parenthesis are angular transformed values with \pm standard error.

Table 3: Growth inhibitory effect of Trichoderma isolates on P. theae.

\begin{tabular}{ll}
\hline Trichoderma isolate & Growth inhibiti \\
\hline T. harzianum $(\mathrm{KBN}-1 / 14)$ & $57.0(49.2 \pm 0.9)$ \\
T. harzianum $(\mathrm{KBN}-2 / 14)$ & $53.8(47.2 \pm 1.0)$ \\
T. viride $(\mathrm{KBN}-24)$ & $61.5(51.5 \pm 0.7)$ \\
T. asperellum $(\mathrm{KBN}-29)$ & $62.5(50.8 \pm 1.5)$ \\
C.D. & 3.2 \\
SE $(\mathrm{m})$ & 1.0 \\
SE $(\mathrm{d})$ & 1.5 \\
C.V. & 4.6
\end{tabular}

*Values represent mean of 5 replications, figures in parenthesis are angular transformed values with \pm standard error

Fungicide compatibility with Trichoderma sp.

Result of present investigation on the susceptibility showed that, the recommended concentrations of all tested fungicides inhibited the growth of $T$. viride (Table 4). However, the maximum inhibition (79.0\%) was noted in case of combi fungicide formulation followed by copper oxychloride (75.8\%) and hexaconazole $(70.4 \%)$. Earlier reports also indicated that various triazole fungicides like hexaconazole, propiconazole and penconazole had high inhibitory influence against $T$. harzianum at varying 
concentrations (Narayana and Srivastava, 2003). Similarly toxic effect of hexaconazole on $T$. viride and T. harzianum was also observed by Johnson (2001). Sarkar et al. (2010) found that systemic fungicides, hexaconazole was the most toxic for $T$. harzianum, however contact fungicides viz., copper oxychloride and copper hydroxide were lesser toxic to this antagonistic fungus. Bagwan (2010) noted that, thiram, copper oxychloride and mancozeb were less toxic against T. harzianum and T. viride.

Table 4. Compatibility of fungicides with T. viride.

\begin{tabular}{lll}
\hline Fungicide & $\begin{array}{l}\text { Fungicide concentration } \\
(\mathbf{p p m})\end{array}$ & $\begin{array}{l}\text { Per cent inhibition of antagonist's growth } \\
\text { after 96 hrs* }\end{array}$ \\
\hline Carbendazim 12\% plus mancozeb 63\% & 2500 & $79.0(62.8 \pm 1.2)$ \\
Copper hydroxide 77 WP & 2500 & $61.6(51.7 \pm 1.5)$ \\
Copper oxychloride 50 WP & 2500 & $75.8(60.5 \pm 0.5)$ \\
Hexaconazole 25 EC & 1000 & $70.4(57.1 \pm 1.3)$ \\
C.D. & - & 3.6 \\
SE $(\mathrm{m})$ & - & 1.2 \\
SE(d) & - & 1.7 \\
C.V. & - & 4.6 \\
\hline
\end{tabular}

*Values represent mean of 5 replications, figures in parenthesis are angular transformed values with \pm standard error

\section{Conclusion}

The findings of the present study showed that, the grey blight disease has a wide occurrence in tea gardens of Dooars region. This pathogen is capable of infecting a large number of tea cultivars with varying degree of infection. Amongst the different fungicides tested, combination of carbendazim plus mancozeb proved to be better for the control of $P$. theae. The indigenous Trichoderma isolates could also effectively control this pathogen. Our study also suggested that, this disease could be efficiently managed by adopting integrated management approach, however taking in to account of the susceptibility of the Trichoderma spp. to the fungicides, care should be taken to ensure sufficient time gap between the applications of fungicide and Trichoderma formulation for achieving better control of the disease.

\section{Conflict of interest statement}

Authors declare that they have no conflict of interest.

\section{Acknowledgement}

The authors are thankful to Dr. T. Prameela Devi, Principal Scientist, Department of Mycology \& Plant Pathology, Indian Agricultural Research Institute, PUSA, New Delhi, for identifying the indigenous Trichoderma isolates. Our sincere thanks are also due to Dr. N. Muraleedharan, Director, TRA, TTRI, Tocklai, Jorhat, for his valuable support and guidance. The financial support rendered in the form of a project from the Biotechnology Industry Research Assistance Council (BIRAC), New Delhi is also gratefully acknowledged.

\section{References}

Agrios, G.N., 2005. Plant Pathology. $5^{\text {th }}$ Edn. Elsevier Academic, USA.

Armstrong-Cho, C.L., Banniza, S., 2006. Glomerella truncata sp. nov., the teleomorph of Colletotrichum truncatum. Mycol. Res. 110, 951-956.

Bagwan, N.B., 2010. Evaluation of Trichoderma compatibility with fungicides, pesticides, organic cakes and botanicals for integerated management of soil borne diseases of soybean (Glycine max (L.) Merril). Int. J. Plant Prot. 3 (2), 206-209.

Barr, M.E., 1975. Pestalosphaeria, a new genus in the Amphisphaeriaceae. Mycologia. 67, 187-194.

Chakraborty, B.N., Basu, P., Das, R., Saha, A., Chakraborty, U., 1995. Detection of cross reactive antigens between Pestalotiopsis theae and tea leaves and their cellular location. Ann. App. Biol. 127 (1), 11-21.

Dominguesa, F.C. Queiroza, J.A., Cabralb, J. M. S., Fonsecab, L. P., 2000. The influence of culture conditions on mycelial structure and cellulose production by Trichoderma reesei rut C-30. Enz. Microbial. Technol. 26, 394-401.

Elad, Y., Chet, I., Henis, Y., 1982. Degradation of plant pathogenic fungi by Trichoderma harzianum. Can. J. Microbiol. 28, 719-725.

Elliott, M.L., Broschat, T.K., Uchida, J.Y., Simone, G.W., 2004. Diseases and disorders of ornamental palms. American Phyto-pathological Society, St. Paul. 
Espinoza, J.G., Briceno, E.X., Keith, L.M., Latorre, B.A., 2008. Canker and twig dieback of blueberry caused by Pestalotiopsis spp. and a Truncatella sp. in Chile. Plant Dis. 92, 1407-1414.

Hopkins, K.E., McQuilken, M.P., 1997. Pestalotiopsis on nursery stock, in HDC Project News No 39. Horticultural Development Council, East Malling.

Hopkins, K.E., McQuilken, M.P., 2000. Characteristics of Pestalotiopsis associated with hardy ornamental plants in the UK. Eur. J. Plant Pathol. 106, 77-85.

Horikawa, T., 1986. Yield loss of new tea shoots due to grey blight caused by Pestalotia longiseta Spegazzini. Bull. Shizuoka Tea Exp. Stn. 12, 1-8.

Johnson, I., 2001. Bioefficacy of hexaconazole 5 SC against rice sheath blight (Rhizoctonia solani Kuhn) and groundnut late leaf spot (Phaeoisariopsis personata (Berk and Curt.) V. Arx), its persistence and residues. Ph. D. Thesis, Tamil Nadu Agricultural University, Coimbatore 641003, 2001.

Joshi, S.D., Sanjay, R., Baby, U.I., Mandal, A.K.A., 2009. Molecular characterization of Pestalotiopsis spp. associated with tea (Camellia sinensis) in southern India using RAPD and ISSR markers. Ind. J. Biotechnol. 8(4), 377-383.

Keith, L.M., Velasquez, M.E., Zee, F.T., 2006. Identification and characterization of Pestalotiopsis spp. causing scab disease of guava, Psidium guajava in Hawaii. Plant Dis. 90, 16-23.

Kirk, P.M., Cannon, P.F., Minter, D.W., Stalpers, J.A., 2008. Dictionary of the Fungi. $10^{\text {th }}$ Edn. CABI, Wallingford.

Kwee, L.T., Chong, K.K., 1990. Guava in Malaysia: production, pests and diseases. Tropical Press SDN. BHD, Kuala Lumpur.

Madar, Z., Solel, Z., Kimchi, M., 1991. Pestalotiopsis canker of Cypress in Israel. Phytoparasitica. 19(1), 79-81.

McQuilken, M.P., Hopkins, K.E., 2004. Biology and integrated control of Pestalotiopsis on container grown ericaceous crops. Pest Manag. Sci. 60, 135-142.

Mondal, K.K., Mani, C., Varma, G., Kumar, R., 2015. Genetic and pathogenic characterization of Xanthomonas axonopodis pv. punicae towards managing bacterial blight of pomegranate. In: Practical manual of CAFT 2015 "Genetic and pathogenic characterization towards managing nationally important plant pathogens causing wilt and blight" ICAR - Indian Agricultural Research Institute, New Delhi. pp.53-69.

Naglot, A., Goswami, S., Rahman, I., Shrimali, D.D., Yadav, K.K., Gupta, V.K., Rabha, A.J., Gogoi, H.K., Veer, V., 2015. Antagonistic potential of native Trichoderma viride strain against potent tea (Camellia sinensis (L.) O. Kuntze) fungal pathogens in North East India. Plant Pathol. J. 31(3), 1-13.

Narayana, B.M., Srivastava, L.S., 2003. Evaluation of some fungicides and neem formulations against six soil borne pathogens and three Trichoderma sp. in vitro. Plant Dis Res. 18, 56-59.
Nene, Y.L., Thapliyal, P.N., 1993. Fungicides in Plant Disease Control. 3rd ed. Oxford and IBH Publishing Company, New Delhi, India pp. 531-532.

Okigbo, R. N., Osuinde, M. I., 2003. Fungal leaf spot diseases of mango (Mangifera indica L.) in Southeastern Nigeria and biological control with Bacillus subtilis. Plant Protect. Sci. 39, 70-77.

Palanisamy, S., Mandal, A. K., 2014. Susceptibility against grey blight disease causing fungus Pestalotiopsis sp. in tea (Camellia sinensis (L.) O. Kuntze) cultivars is influenced by anti-oxidative enzymes. Appl. Biochem. Biotechnol. 172(1), 216-23.

Pandey, R. R., 1990. Mycoflora associated with floral parts of guava (Psidium guajava L.). Acta Bot. Sin. 18, 59-63.

Papavizas, G.C., 1985. Trichoderma and Gliocladium: Biology, Ecology and their potential for biological control. Ann. Rev. Phytopathol. 51, 693-699.

Pirone, P. P., 1978. Diseases and pests of ornamental plants. Wiley Interscience, New York.

Ponmurugan, P., Baby, U.I., Gopi, C., 2006. Efficacy of certain fungicides against Phomopsis theae under in vitro conditions. Afr. J. Biotechnol. 5 (5), 434-436.

Ridout, C. J., Coley, Smith, J.R., Lynch, J.M., 1988. Fractionation of extracellular enzymes from a mycoparasitism strain of Trichoderma harzianum. Enz. Microb. Technol. 10, 180-187.

Sarkar, S., Ajay, D., Pradeepa, N., Balamurugan, A., Premkumar, R., 2009. Evaluation of chemical and neem pesticides against Pestalotiopsis theae causing grey blight disease of tea. Ann. Plant Protect. Sci. 17(1), 252-253.

Sarkar, S., Narayanan, P., Divakaran, A., Balamurugan, A., Premkumar, R., 2010. The in vitro effect of certain fungicides, insecticides, and biopesticides on mycelial growth in the biocontrol fungus Trichoderma harzianum. Turk. J. Biol. 34, 399-403.

Sousa, M.F., Tavares, R.M., Gerós, H., Lino-Neto, T., 2004. First report of Hakea sericea leaf infection caused by Pestalotiopsis funerea in Portugal. Plant Pathol. 53, 535.

Stack, J.P., Kenerley, C.M., Petti, R.E., 1986. Application of biological control agents. In: Biological Control of Plant Diseases. Butterworth, London. 71p.

Tagne, A., Mathur, S.B., 2001. First report of chlorotic spot of maize caused by Pestalotiopsis neglecta. Plant Pathol. 50, 791.

Taylor, A., 1986. Some aspects of the chemistry and biology of the genus Hypocrea and its anamorphs, Trichoderma and Gliocladium. Proc. N.S. Inst. Sci. 36, 1127-1158.

Vidhya Pallavi, R., Nepolean, P., Balamurugan, A., Jayanthi, R., Beulah, T., Premkumar, R., 2012. In vitro studies of biocontrol agents and fungicides tolerance against grey blight disease in tea. Asian Pac. J. Trop. Biomed. S435-S438.

Vidhya Pallavi, R., Nepolean, P., Balamurugan, A., Pradeepa, N., Kuberan, T., 2010. In-vitro studies on antagonistic potential of biocontrol agents against tea pathogens, Hypoxylon sp. and Pestalotiopsis sp. Rubber Research Institute of India, Kottayam. pp. 172-173. 
Wulandari, N.F., To-anun, C., Hyde, K.D., Duong, L.M., de Gruyter, J., Meffert, J.P., Groenewald, J.Z., Crous, P.W., 2009. Phyllosticta citriasiana sp. nov., the cause of citrus tan spot of Citrus maxima in Asia. Fungal Divers. 34, 2339.
Xu, L., Kusakari, S., Hosomi, A., Toyoda, H., Ouchi, A., 1999. Postharvest disease of grape caused by Pestalotiopsis species. Ann. Phytopathol. Soc. Japan. 65, 305-311.

\section{How to cite this article:}

Kumhar, K.C., Babu, A., Bordoloi, M., Benarjee, P., Rajbongshi, H., 2016. Comparative bioefficacy of fungicides and Trichoderma spp. against Pestalotiopsis theae, causing grey blight in tea (Camellia sp.): An in vitro study. Int. J. Curr. Res. Biosci. Plant Biol. 3(4), 20-27. doi: $\underline{\text { http://dx.doi.org/10.20546/ijcrbp.2016.304.004 }}$ 